\title{
Infección quirúrgica en cirugía maxilofacial
}

\section{Cross Infection in maxillofacial surgery}

\author{
J. Martínez-Checa', V. Fuentes Gómez², E. Jiménez Romano33, M.T. León Espinosa de los Monteros², \\ M. Llamas del Castillo3, M.J. Bermejo Pérez², J. Planes Martínez ${ }^{4}$
}

Resumen: Objetivos. Determinar la incidencia de infección del lecho quirúrgico en un Servicio de Cirugía Maxilofacial que atiende a una población de 818.959 habitantes y analizar los factores de riesgo implicados en la misma. Método. Estudio de cohorte prospectivo (septiembre 1999noviembre 2000). Se incluyeron a todos los pacientes intervenidos quirúrgicamente por patología maxilofacial en este Servicio excepto aquellos ingresados por cuadros de celulitis odontógena y los sometidos a extracciones dentarias. Población total de estudio $=382$. Seguimiento hasta treinta días posteriores a la intervención o un año si se requirió osteosíntesis.

Diagnóstico de infección según criterios CDC. Análisis estadístico. bivariante, (Chi cuadrado, t-Student y regresión logística simple) y análisis multivariante (regresión logística múltiple). Paquete estadístico SPSS 10.0. Resultados. La incidencia total de infección quirúrgica fue del 9,4\%. En cirugía traumatológica fue del 1.8\%, en no traumatológica del 15,5\%. Dentro de esta última, en procesos benignos, la incidencia de infección fue del $2,9 \%$ y en procesos malignos $20,9 \%$. En el análisis multivariable resultaron como factores predictores de infección el tiempo de intervención superior a dos horas (OR=7, IC95\%: 3,01-16,25), el grado de contaminación de la herida $(O R=7,20, I C 95 \%: 1,25-26,52)$ y la reintervención quirúrgica (OR=6,29, IC95\%:2,64-14,94). La incidencia de infección aumenta escalonadamente para cada unidad de incremento del índice NISS (Nacional Nosocomial Infection Surveillance) (OR=3,61, IC95\%:2,38-5,60). Conclusiones. La incidencia de infección del sitio quirúrgico en cirugía traumatológica maxilofacial es baja, mientras que en cirugía no traumatológica es similar a la aportada por otros estudios. Los factores que de manera independiente se asocian a la infección son el tiempo de intervención, el grado de contaminación de la herida y la reintervención quirúrgica.La incidencia de infección aumenta a mayor puntuación del índice NISS.

Palabras clave: Infección Quirúrgica; Factores de Riesgo; Cirugía Maxilofacial.
Abstract: Objectives. To determine the incidence of infection in the surgical site at the maxillofacial surgical unit and to analyse the risk factors related to the infection. Methods. A prospective cohort study ran from September 1999 to November 2000. The study included all patients under a surgical intervention at this unit except those admitted because of gums infected by their teeth and those under dental extraction who required admission. The total study numbered 382 people. The follow up of the patients lasted 30 days after the surgical intervention or one year if the patient required maxillofacial prosthesis implantation. The statistical analysis included bivariant (chi square, $t$-student and simple logit regression) and multivariant analysis (multiple logit regression). Results. The total incidence of infection in the surgical site was 9,4\%. Infection incidence of orthopaedic maxillofacial surgery was 1,8\% and non-orthopaedic was $15,5 \%$. In non-orthopaedic maxillofacial surgery, infection incidence in benign processes was 2,9\% and in malign processes was $20,9 \%$. From the multivariant analysis, surgical intervention time over 2 hours (OR=7; Cl 95\%: 3,01-16,25), the contamination degree of the surgical wound (OR=7,20; $\mathrm{Cl} 95 \%: 1,25-26,52)$ and surgical re-intervention ( $O R=6,29 ; \mathrm{Cl} 95 \%: 2,64-14,94)$ came up as the predictor factors of infection. The incidence of infection increases as NISS Index units raises (OR=3,61; CI 95\%: 2,38-5,60). Conclusions. The incidence of infection in the surgical site in orthopaedic maxillofacial surgery is low, whilst in non-orthopaedic surgery is similar to the ones reported by other studies. Independent factors related to the infection are surgical intervention time of over 2 hours, the contamination degree of the surgical wound and the surgical re-intervention. The incidence of infection increases as NISS Index units raise.

Key words: Cross Infection; Risk Factors; Maxillofacial Surgery.

\footnotetext{
1 Enfermera.

2 Médico residente.

3 Médico adjunto.

4 Jefe de Servicio.

Servicio de Cirugía Oral y Maxilofacial.

Servicio de Medicina Preventiva.

Hospital Universitario Virgen de las Nieves. Granada. España.
} 


\section{Introducción}

La infección nosocomial quirúrgica derivada de la Cirugía Maxilofacial tiene algunas connotaciones diferentes a las de otros tipos de cirugía. Por un lado se realiza en territorios, como es la boca, con un alto contenido en gérmenes aerobios y anaerobios. Por otro lado, existen pocas publicaciones referentes a la infección tras cirugía mayor de la cavidad oral y de la región orofaringea en la bibliografía.

Nuestro objetivo es aportar el resultado del estudio de incidencia de infección del sitio quirúrgica en el Servicio de Cirugía Maxilofacial del Hospital Universitario Virgen de las Nieves de Granada y estudiar algunos factores de riesgo implicados en la misma.

\section{Material y método}

Se realizó un estudio prospectivo de cohortes en el Servicio de Cirugía Maxilofacial del Hospital Universitario Virgen de las Nieves. Periodo de estudio desde el 15 de septiembre de 1999 al 15 de noviembre de 2000 . Se incluyeron todos los pacientes ingresados y sometidos a intervenciones quirúrgicas en este Servicio. Se excluyeron del estudio: $1^{\circ}$ Aquellos casos que ingresaron para intervención por celulitis tras infección odontógena, fuese o no precedida de extracción dentaria, $2^{\circ}$ los casos de enfermos sometidos a extracciones dentarias y que requirieron ingreso hospitalario por ser minusvalidos psíquicos o presentar alguna otra anomalía y $3^{\circ}$ los casos que sufrieron exitus en los siete días siguientes a la intervención y no presentaron infección del sitio quirúrgico.

La población de estudio estuvo constituida por una cohorte de 382 pacientes.

El seguimiento se llevó a cabo durante los treinta días siguientes a la intervención, prolongándose a un año en los casos en que se realizó osteosíntesis.

La recogida de la información se llevó a cabo mediante protocolos individualizados en los que constaban los siguientes datos: nombre, edad, sexo, número de historia, fecha de ingreso, diagnóstico principal y secundarios, profilaxis antibiótica, tipo y tiempo de la misma, fecha y tipo de intervención, grado de contaminación de la herida quirúrgica, duración del tiempo quirúrgico, existencia de comunicación oral, grado ASA del paciente (según la clasificación de la American Society of Anesthesiologists ${ }^{1}$ ), cirujano principal, reintervenciones en un intervalo no superior a un mes, fecha de infección nosocomial y germen responsable, por último fecha de alta hospitalaria. ${ }^{1}$

Siguiendo el estudio del Nacional Nosocomial Infection SurveiIlance NNIS, ${ }^{3}$ agrupamos a nuestros enfermos en cuatro grupos:

1. Puntuación 0. Enfermos con ASA $<3$, tiempo de intervención menor de dos horas y grados de contaminación de herida quirúrgica de los grupos limpia y limpia contaminada.

2. Puntuación 1. Enfermos con $A S A \geq 3$ o tiempo de intervención mayor de 2 horas o grado de contaminación de herida quirúrgica en el grupo de contaminada o sucia.

\section{Introduction}

Nosocomial surgical infection derived from Maxillofacial Surgery has some different connotations than those of other types of surgery. On the one hand, it occurs in territories, such as the mouth, that have a high content of aerobic and anerobic germs. On the other hand, few publications referring to infection after major surgery of the oral cavity and the oropharyngeal region are found in the bibliography.

Our objective is to provide the study result of the infection incidence in the surgical site in the Maxillofacial Surgery Service of the University Hospital Virgen de las Nieves of Granada and to study some risk factors involved in it.

\section{Material and Method}

A prospective study of cohorts was performed in the Maxillofacial Surgery Service of the University Hospital Virgen de las Nieves. The study period ranged from September 15, 1999 to November 15, 2000. All the patients hospitalized who underwent surgical interventions in this Service were included. The following patients were excluded from the study: 1) Those cases that were admitted for surgical intervention due to cellulitis after odontogenic infection, regardless of whether it was preceded by dental extraction, 2) cases of patients who underwent dental extractions and who required hospitalization because they had psychic incapacity or because they presented some other abnormality and 3) those cases that suffered exitus in the seven days following the surgical intervention and did not present infection of the surgical site.

The study population was made up of a cohort of 382 patients.

The follow-up was carried out for thirty days after the surgery, this being prolonged to one year in the cases in which an osteosynthesis was performed.

Information was collected with individualized protocols that included the following data: name, age, gender, clinical record number, admission date, main and secondary diagnosis, antibiotic prophylaxis, its type and time, date and type of surgical intervention, contamination degree of the surgical wound, surgical time duration, existence of oral communication, ASA grade of the patient (according to the American Society of Anesthesiologists), ${ }^{1}$ main surgeon, surgical reinterventions in an interval that does not surpass one month, date of nosocomial infection and responsible germ, and finally, date of hospital discharge?.

According to the National Nosocomial Infection Surveillance ${ }^{3}$ NNIS Study, we classified our patients into four groups:

1. Score 0 . Patients with $A S A<3$, surgical intervention time less than two hours and surgical wound contamination grades of the groups clean and clean contaminated. 
Tabla 1. Edad de infección.

$\begin{array}{lccc}\text { Edad } & \begin{array}{c}\mathbf{N}^{\circ} \text { Total de } \\ \text { intervenciones }\end{array} & \mathbf{N}^{\circ} \text { de infecciones } & \% \\ \text { 0-19 años } & 57(14,9 \%) & 3 & 5,3 \\ \text { 20-39 años } & 135(35,3 \%) & 3 & 2,2 \\ \text { 40-59 años } & 76(19,9 \%) & 7 & 9,2 \\ \text { 60-79 años } & 96(25,1 \%) & 21 & 21,9 \\ \geq 80 \text { años } & 18(4,7 \%) & 2 & 11,1 \\ \text { Totales } & 382(100 \%) & 36 & 9,4\end{array}$

3. Puntuación 2. Enfermos con dos de los parámetros de riesgo (ASA superior a 3, tiempo superior a 2 horas o herida contaminada/sucia).

4. Puntuación 3. Enfermos con los tres parámetros de riesgo.

El diagnóstico de infección se realizó siguiendo los criterios de los CDC (1992). ${ }^{2}$

\section{Análisis estadístico}

Se realizó un análisis bivariante para estudiar la asociación entre los posibles factores de riesgo y el desarrollo de infección nosocomial. Se empleó el test de Chi cuadrado para variables dicotómicas; el test t-Student para la comparación de medias entre grupos y la regresión logística simple para las numéricas continuas. La asociación estadística se realizó en términos de riesgo relativo e intervalo de confianza del 95\%. También se llevó a cabo un análisis multivariante mediante regresión logística múltiple para identificar los factores predictores independientes de infección de la herida quirúrgica.

La base de datos y el análisis se realizaron con el paquete estadístico SPSS 10,0 para Windows.

\section{Resultados}

La población total de estudio fue de 382 pacientes, de ellos presentaron infección de la herida quirúrgica 36 , lo que representa una incidencia global del 9,4\%.

\section{Parámetros del estudio}

1. Edad

La edad media de la población fue de 43.38 años, con un rango entre 2 y 91 años.

En la tabla 1, se estudia la relación entre grupos de edad e infección.

Si comparamos la incidencia de infección de cada grupo de edad con el resto de la muestra, obtenemos para el grupo de 20 a 39 años un RR de 0,16 (0,05-0,53), $p<0,005$; para el grupo de 60 a 79 años el RR es de $4,17(2,24-7,76), p<0,005$. Los otros grupos de edad no arrojaron datos significativos.
Table 1. Age and infection.

$\begin{array}{lccc}\text { Edad } & \begin{array}{c}\text { Total } \mathbf{N}^{\circ} \text { of surgical } \\ \text { intervenciones }\end{array} & \begin{array}{c}\mathbf{N}^{\circ} \text { of } \\ \text { infections }\end{array} & \text { \% } \\ \text { 0-19 years } & 57(14.9 \%) & 3 & 5.3 \\ \text { 20-39 years } & 135(35.3 \%) & 3 & 2.2 \\ \text { 40-59 years } & 76(19.9 \%) & 7 & 9.2 \\ \text { 60-79 years } & 96(25.1 \%) & 21 & 21.9 \\ \geq 80 \text { years } & 18(4.7 \%) & 2 & 11.1 \\ \text { Totals } & 382(100 \%) & 36 & 9.4\end{array}$

2. Score 1. Patients with $A S A \geq 3$ or surgical intervention time greater than 2 hours or surgical wound contamination grade in the group of contaminated or dirty.

3. Score 2. Patients with two of the risk parameters (ASA superior to 3 , time superior to 2 hours or contaminated/dirty wound).

4. Score 3. Patients with three risk parameters.

The diagnosis of infection was performed following the CDC criteria (1992). ${ }^{2}$

\section{Statistical analysis}

A bivariate analysis to study the association between the possible risk factors and the development of nosocomial infection was performed. The Chi squared test for dichotomic variables, the Student's $t$ test for the comparison of means between groups and the simple logistic regression for continuous numbers were used. Statistical association was performed in terms of relative risk and $95 \%$ confidence interval.

A multivariate analysis was also performed by multiple logistic regresion to identify the predictor factors independent of surgical wound infection.

The database and analysis were performed with the SPSS 10.0 for Windows statistical program.

\section{Results}

The total population of the study was 382 patients, 36 of whom presented surgical wound infection, which represents a global incidence of $9.4 \%$.

Study parameters:

1. Age

The mean age of the population was 43.38 years, with a range between 2 and 91 years.

The relationship between age groups and infection is studied in table 1.

If we compare the infection incidence of each age group with the rest of the sample, we obtain a RR of 0.16 (0.05$0.53), p<0.005$ for a group of 20 to 39 years; the $R R$ is 4.17 
Tabla 2. Días estancia hospitalaria.

\begin{tabular}{|c|c|c|c|}
\hline Tipo estancia & Global & Infectados & No infectados \\
\hline $\begin{array}{l}\text { Días } \\
\text { estancia media }\end{array}$ & $\begin{array}{c}13,37 \\
\text { (rango=1-157) }\end{array}$ & 37,5 & 10,8 \\
\hline $\begin{array}{l}\text { Estancia } \\
\text { preoperatoria } \\
\text { media }\end{array}$ & $\begin{array}{c}4,51 \\
(\text { rango=0-39) }\end{array}$ & 8,2 & 4,1 \\
\hline
\end{tabular}

\section{Sexo}

Se realizaron 282 intervenciones en hombres $(73,8 \%)$ con 31 infecciones (11\%) y 100 en mujeres $(26,2 \%)$ con 5 infecciones (5\%). Aunque la relación riesgo infección hombre/mujer es de 2,35 (IC 95\%: 0,88-6,21), no observamos diferencias estadísticamente significativas, $p=0,078$.

\section{Profilaxis antibiótica}

Se realizó profilaxis antibiótica en 323 pacientes (84,6\%). En 231 de ellos, se utilizó amoxiclavulánico a la dosis de 1 gramo cada 6 horas; en 72 casos, se utilizó clindamicina a la dosis de 300 mg. cada 8 horas y en 20 casos, se utilizaron otros antibióticos (curoxima, cloxacilina, vancomicina, etc.). El tiempo de utilización no fue bien definido y dependió del criterio de cada cirujano, en la mayoría de los casos, estuvo comprendido entre 24 horas y siete días.

En 59 casos (15,4\%), no se efectúo profilaxis antibiótica. Se trataba de pequeñas intervenciones, limpias, sin osteosíntesis y de corta duración.

\section{Incidencia de infección}

Se dividió a los pacientes en dos grupos: a) cirugía traumatológica y b) no traumatológica. Al primer grupo correspondieron 169 enfermos $(44,2 \%)$ de los que se infectaron $3(1,8 \%)$, mientras que al segundo grupo pertenecieron 213 (55,8\%), de los que se infectaron $33(15,5 \%)$. El RR para la cirugía no traumatológica fue de 8,73 (IC 95\%: 2,72-27,97). La diferencia de infección es ampliamente significativa, con $p<0,005$.

\section{Estudio de estancia hospitalaria}

Dos parámetros hemos estudiado bajo este punto de vista, los días totales de estancia y los días de estancia preoperatoria; y comparamos los resultados entre enfermos infectados y no infectados (Tabla 2).

La estancia media en infectados es 3,47 veces superior a la de no infectados, diferencia estadística significativa $(p<0,005)$. La demora de la intervención (tiempo de estancia preoperatoria media) es dos veces superior en los infectados que en los no infectados con una diferencia estadísticamente significativa ( $p<$ 0,005).

\section{Duración de la intervención}

La duración media de la intervención es de 137,5 minutos, 2,6 veces superior en infectados frente a no infectados con $p<0,005$ (Tabla 3).
Table 2. Days of hospital stay.

$\begin{array}{lccc}\text { Stay type } & \text { Global } & \text { Infected } & \text { Non-ifected } \\ \begin{array}{l}\text { Mean } \\ \text { days of stay }\end{array} & \begin{array}{c}13,37 \\ \text { (range=1-157) }\end{array} & 37,5 & 10,8 \\ \begin{array}{l}\text { Mean } \\ \text { pre-operation } \\ \text { stay }\end{array} & \begin{array}{c}4,51 \\ \text { (range }=0-39)\end{array} & 8,2 & 4,1\end{array}$

(2.24-7.76), $p<0.005$ for the $60-79$ year old group. The other age groups did not provide significant data.

\section{Gender}

A total of 282 surgical interventions were performed in men (73.8\%) with 31 infections (11\%) and 100 in women (26.2 \%) with 5 infections (5\%). Although the man/woman infection risk ratio is 2.35 (95\% Cl: 0.88-6.21), we did not observe statistically significant differences, $p=0.078$.

\section{Antibiotic prophylaxis}

Antibiotic prophylaxis was performed in 323 patients (84.6\%). In 231 of them, amoxyclavulanic acid was used at a dose of 1 gram every 6 hours. In 72 cases, clindamycin was used at the dose of $300 \mathrm{mg}$. every 8 hours and other antibiotics were used in 20 cases (cefuroxime, cloxacillin, vancomycin, etc.). The usage time was not well defined and depended on the criterion of each surgeon. It ranged from 24 hours to seven days in most of the cases.

In 59 cases (15.4\%), no antibiotic prophylaxis was performed. These were small surgical interventions, clean, without osteosynthesis that had a short duration.

\section{Infection incidence}

The patients were divided into two groups: a) traumatological surgery and $b$ ) non-traumatological surgery. There were 169 patients (44.2\%) in the first group, 3 (1.8\%) of whom were infected, while the second group had 213 (55.8\%), 33 (15.5\%) of whom were infected. The RR for non-traumatological surgery was 8.73 (95\% Cl: 2.72-27.97). The difference of infection is very significant, with $p<0.005$.

\section{Study of hospital stay}

We have studied two parameters under this point of view, the total days of stay and the days of pre-operative stay. We compared the results between infected and non-infected patients (Table 2).

The mean stay of the infected patients is 3.47 times greater than the non-infected ones, a statistically significant difference $(p<0.005)$. Delay in the surgical intervention (mean pre-operative stay time) is two times greater in the infected patients than the non-infected ones with a statistically significant difference $(p<0.005)$. 
Tabla 3. Duración Intervención

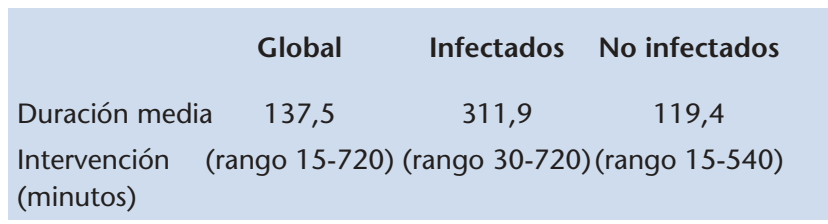

Tabla 4. Tiempo T de intervención

$\begin{array}{cccc} & \begin{array}{c}\text { Intervenciones } \\ \text { totales }\end{array} & \text { Infectados } & \% \text { infección } \\ \geq 2 \text { horas } & 249 & 7 & 2,8 \\ <2 \text { horas } & 133 & 29 & 21,8\end{array}$

Table 3. Duration of Intervention.

$\begin{array}{cccc} & \text { Global } & \text { Infected } & \text { Non-Infected } \\ \text { Mean surgical } & 137.5 & 311.9 & 119.4\end{array}$

Intervention (range 15-720)(range 30-720)(range 15-540) duration (minutes)

Table 4. T time of surgical intervention.

$\begin{array}{lccc} & \begin{array}{c}\text { Total surgical } \\ \text { interventions }\end{array} & \text { Infected } & \text { \% infection } \\ \geq 2 \text { hours } & 249 & 7 & \\ <2 \text { hours } & 133 & 29 & 21.8\end{array}$

Para comparar resultados con el estudio NNIS (National Nosocomial Infection Surveillance), se fijó el tiempo T (75 percentil del tiempo empleado en las distintas intervenciones) en 2 horas, aunque en algunas cirugías (oncológicas), este tiempo sería muy superior.

La diferencia de infección entre los enfermos con tiempo de intervención menor o igual a dos horas y aquellos con tiempo superior a dos horas es estadísticamente significativa con $p<0,005$. El RR para las intervenciones de más de dos horas fue de 7,65 (IC 95\%: 3,49-17,23) (Tabla 4).

\section{Clasificación ASA}

Según el estudio NNIS se divide a los pacientes en dos amplios grupos: grado ASA $\leq 2$ con un total de 332 (86,9\%), los cuales presentaron 28 infecciones $(8,4 \%)$ y grado ASA $\geq 3$, que fueron 50 $(13,1 \%)$ con 8 infecciones (16\%). No observamos asociación estadísticamente significativa entre el grado ASA del paciente y la infección nosocomial (RR: 1,$9 ; 0,91-3,92), p=0,08$.

\section{Diferencia entre procesos malignos y benignos}

Hemos introducido este parámetro, considerando que la existencia de un proceso maligno representa un factor de riesgo por muchas circunstancias (alteración en la inmunidad, tratamiento con citostáticos o radiaciones, etc.) y atendiendo a ello el estudio entre procesos benignos y malignos, produjo los siguientes resultados: Procesos benignos intervenidos $243(63,6 \%)$ con 7 infecciones $(2,9 \%)$ y procesos malignos intervenidos $139(36,4 \%)$ con 29 infecciones (20,9\%). La significación estadística es evidente con $p<0,005$. RR para el grupo de enfermos con procesos malignos de 7,24 con un IC $95 \%$ de 3,26-16,09.

\section{Grado de contaminación de la herida}

Según este parámetro pertenecen al grupo de cirugía limpia o limpia contaminada un total de $337(88,2 \%)$ con 31 infecciones $(9,2 \%)$ y al grupo de cirugía contaminada o sucia $45(11,8 \%)$ con 5 infecciones $(11,1 \%)$. La diferencia de infección en el análisis bivariante no tiene significación estadística $(p=0,68)$, sin embargo, si estratificamos atendiendo a la variable benigno-maligno (test de Cochran: $p<0,05)$ obtenemos que la variable grado de contamina-
6. Duration of surgical intervention

Mean duration of the surgical intervention is $137.5 \mathrm{~min}$ utes, 2.6 times greater in the infected patients than in the non-infected ones with $p<0.005$ (Table 3).

To compare the results with the NNIS (National Nosocomial Infection Surveillance) study, T time (75 percentile of time used in the different surgical interventions) was established at 2 hours, although this time was greater in some surgeries (oncologic).

The difference of infection between patients with surgical intervention time less than or equal to two hours and those with a time superior to two hours is statistically significant with $a p<0.005$. The RR for the surgical interventions of more than two hours was 7.65 (95\% Cl: 3.49-17.23) (Table 4).

\section{ASA Classification}

According to the NNIS study, the patients were divided into two large groups: ASA grade $\leq 2$ with a total of 332 (86.9\%), 28 of which presented infections (8.4\%) and ASA grade $\geq 3$, with 50 (13.1\%), 8 of which presented infections (16\%). We have not observed a statistically significant association between the ASA grade of the patient and the nosocomial infection (RR: 1.9; 0.91-3.92), $p=0.08$.

\section{Difference between malignant and benign conditions}

We have introduced this parameter, considering that the existence of a malignant condition represents a risk factor due to many circumstances (alteration in immunity, treatment with cytostatics or radiations, etc.). On these bases, the study between benign and malignant conditions produced the following results: benign conditions operated on 243 (63.6\%) with 7 infections (2.9\%) and malignant conditions operated on 139 (36.4\%) with 29 infections (20.9 $\%)$. The statistical significance is clear with $p<0.005$. RR for the patient group with malignant conditions was 7.24 with a $95 \% \mathrm{Cl}$ of 3.26-16.09.

\section{Wound contamination degree}

According to this parameter, 337 (88.2\%) with 31 infec- 
Tabla 5. Infección y comunicación oral

$\begin{array}{lccc} & \begin{array}{c}\text { Total } \\ \text { intervenciones }\end{array} & \text { Infecciones } & \% \\ \begin{array}{l}\text { Orales/ } \\ \text { comunicación oral }\end{array} & 195(55 \%) & 25 & 12,8 \\ \begin{array}{l}\text { Sin comunicación oral } \\ 187(49 \%)\end{array} & 11 & 5,9\end{array}$

Tabla 6. Infección y comunicación oral en procesos malignos

$\begin{array}{lccc} & \begin{array}{c}\text { Total } \\ \text { intervenciones }\end{array} & \text { Infecciones } & \% \\ \begin{array}{l}\text { Orales/ } \\ \text { comunicación oral }\end{array} & 93 & 25 & 26,9 \\ \begin{array}{l}\text { Sin comunicación oral } \\ \text { in }\end{array} & 46 & 4 & 8,7\end{array}$

Table 5. Infection and oral communication.

\begin{tabular}{|c|c|c|c|}
\hline & $\begin{array}{l}\text { Total surgical } \\
\text { interventions }\end{array}$ & Infections & $\%$ \\
\hline $\begin{array}{l}\text { Oral/ oral } \\
\text { communication }\end{array}$ & $195(55 \%)$ & 25 & 12.8 \\
\hline Without oral con & on $187(49 \%)$ & 11 & 5.9 \\
\hline
\end{tabular}

Table 6. Infection and oral communication in malignant conditions.

$\begin{array}{lccc} & \begin{array}{c}\text { Total surgical } \\ \text { interventions }\end{array} & \text { Infections } & \% \\ \begin{array}{lccc}\text { Oral/ oral } \\ \text { communication }\end{array} & 93 & 25 & 26.9 \\ \begin{array}{l}\text { Without oral communication } \\ \text { Withe }\end{array} & 46 & 4 & 8.7\end{array}$

ción se encuentra asociada a la variable infección. El test de homogeneicidad positivo permite aceptar una estimación de riesgo de 6,08 (IC 95\%: 1,56-23,73) para el grupo de cirugía contaminadasucia.

Los resultados referentes a la contaminación del campo quirúrgico, considerando por un lado, las intervenciones orales o con comunicación oral y por otro lado, aquellas que no se realizan en este territorio ni tienen comunicación oral se exponen en la tabla 5.

El RR para las intervenciones orales/con comunicación oral es de 2,17 con IC 95\% de 1,10-4,30. La diferencia de infección es estadísticamente significativa $p=0,02$.

Si seleccionamos únicamente aquellos casos no traumatológicos y además malignos, este mismo parámetro de intervenciones realizadas en cavidad oral/comunicación oral, y aquellas otras sin comunicación oral arrojan los siguientes resultados (Tabla 6):

La diferencia de infección entre estos dos grupos es estadísticamente significativa, con $p=0,013$, y el RR en el grupo de enfermos con intervenciones de procesos malignos de cavidad oral/comunicación oral es de 3,10 (IC 95\%: 1,14-8,36).

\section{Reintervención}

Atendiendo a esta variable, dividimos a los enfermos en dos grupos: aquellos que sufrieron dos o más intervenciones con intervalos no superiores a un mes y que representaron la cifra de $27(7,1 \%)$ con 12 infecciones $(44,4 \%)$ y aquellos otros en los que se realizó una sola intervención 355 (92,9\%) con 24 infecciones (6,8\%). La diferencia tiene significación estadística; $p<0,005$. RR para el grupo con reintervención de 6,57 con un IC 95\% de 3,71-11,65.

\section{Indice NNIS3,4}

Si considerásemos el índice NISS como una variable continua, y aplicando la regresión logística simple, obtendríamos una OR para cada unidad de incremento de la variable de 3,61 (IC 95\%: 2,385,60) (Tabla 7). tions (9.2\%) belong to the clean or clean contaminated surgery group and 45 (11.8\%) with 5 infections (11.1\%) to the contaminated or dirty surgery group. The difference of infection in the bivariate analysis has no statistical significance $(p=0.68)$, however, if we stratify according to the benign-malignant variable (Cochran test: $p<0.05)$, we find that the variable contamination degree is associated to the infection variable. The positive homogenecity test allows us to accept a risk estimation of 6.08 (95\% Cl: 1.56-23.73) for the contaminated-dirty surgery group.

Table 5 shows the results regarding the contamination of the surgical field, considering, on the one hand, the oral surgical interventions or those with oral communication, and on the other, those that were not performed in this territory and do not have oral communication.

The RR for the oral/with oral communication interventions was 2.17 with $95 \% \mathrm{Cl}$ of $1.10-4.30$. The infection difference was statistically significant $p=0.02$.

If we only select those non-traumatologic and malignant cases, this parameter of surgical interventions performed in the oral cavity/oral communication and the others without oral communication provide the following results (Table 6).

The difference of infection between these two groups is statistically significant, with $p=0.013$, and the RR in the group of patients with surgical interventions of malignant conditions of the oral cavity/oral communication is 3.10 (95\% Cl: 1.14-8.36).

\section{Reintervention}

Considering this variable, we divided the patients into two groups: those who suffered two or more surgical interventions with intervals not exceeding one month and that represented the value of 27 (7.1\%) with 12 infection (44.4\%) 
Tabla 7. Puntuación de riesgo NNIS e infección.

$\begin{array}{cccc}\text { Indices NNIS } & \text { Total interv. } & \text { Infectados } & \% \\ 0 & 189 & 5 & 2,6 \\ 1 & 160 & 22 & 13,8 \\ 2 & 31 & 7 & 22,6 \\ 3 & 2 & 2 & 100\end{array}$

Tabla 8. Gérmenes responsables de la infección.

$\begin{array}{lcc}\text { Tipo } & \text { Numero total } & \% \\ \text { Flora mixta } & 13 & 33,3 \\ \text { Pseudomona aeruginosa } & 4 & 10,3 \\ \text { Escherichia coli } & 3 & 7,7 \\ \text { Staphylococcus aureus } & 2 & 5,1 \\ \text { Otros (Proteus, Serratia, etc.) } & 6 & 15,4 \\ \text { No identificados } & 11 & 28,2 \\ \text { Totales } & 39 & 100,0\end{array}$

\section{Análisis multivariante}

En el análisis de regresión logística múltiple se introdujeron todas las variables estudiadas, tanto las que arrojaron resultados significativos en el análisis bivariante, como las que fueron consideradas de interés epidemiológico para el estudio resultando factores predictores independientes de infección 3 variables: Un tiempo de intervención mayor de dos horas (OR: 7; 3,01-16,25), el grado de contaminación de la herida (OR: 7,$20 ; 1,25-26,52)$ y la reintervención quirúrgica en un tiempo inferior a un mes (OR: 6,29; 2,6414,94). La amplitud de los intervalos de confianza mejoraría si dispusiésemos de un número mayor de casos.

\section{Gérmenes responsables}

En la tabla 8, indicamos los gérmenes responsables de la infección. El 33,3\% era flora mixta (aerobia y anaerobia, representativa de la flora que coloniza la cavidad bucal), en 11 casos $(28,2 \%)$ no se identificó al germen responsable, en cinco de ellos por no efectuar toma para estudio microbiológico y en los seis restantes por no existir crecimiento bacteriano. En los 11 casos existía exudado purulento. El número total de gérmenes supera en 3 al número de infecciones porque en el estudio microbiológico se identificaron tres muestras con crecimiento de dos gérmenes.

\section{Discusión}

La incidencia de infección en intervenciones menores como las exodoncias, es muy baja, menor del 1\%,5 pero en intervenciones mayores, el porcentaje de infección, se eleva considerablemente, pudiendo llegar hasta cifras superiores al $40 \%$.

La incidencia de infección de la herida quirúrgica en el total de intervenciones del Servicio de Maxilofacial de nuestro Centro fue del 9,4\%. En las intervenciones traumatológicas el porcentaje
Table 7. NISS risk score and infection.

$\begin{array}{cccc}\text { NNIS Index } & \text { Total interv. } & \text { Infected } & \% \\ 0 & 189 & 5 & 2.6 \\ 1 & 160 & 22 & 13.8 \\ 2 & 31 & 7 & 22.6 \\ 3 & 2 & 2 & 100\end{array}$

Table 8. Germs responsible for the infection.

$\begin{array}{lcc}\text { Type } & \text { Total number } & \% \\ \text { Mixed flora } & 13 & 33.3 \\ \text { Pseudomonas aeruginosa } & 4 & 10.3 \\ \text { Escherichia coli } & 3 & 7.7 \\ \text { Staphylococcus aureus } & 2 & 5.1 \\ \text { Others (Proteus, Serratia, etc.) } & 6 & 15.4 \\ \text { Not identified } & 11 & 28.2 \\ \text { Totals } & 39 & 100.0\end{array}$

and those others in which only one surgical intervention was performed, 355 (92.9\%) with 24 infections (6.8\%). The difference had statistical significance; $p<0.005$. The RR for the reintervention group was 6.57 with a $95 \% \mathrm{Cl}$ of 3.71 . 11.65 .

\section{NNIS Index 3,4}

If we consider the NISS index as a continuous variable and apply the simple logistic regression, we will obtain an OR for each increase unit of the variable of 3.61 (95\% Cl: 2.38-5.60) (Table 7).

\section{Multivariate analysis}

In the multiple logistic regression analysis, all the variables studied were introduced. These included both those that provided significant results in the bivariate analysis as well as those that were considered to have an epidemiologic interest for the study, there being 3 factors that were independent predictive factors of infection: a surgical intervention time over two hours (OR: 7; 3.01-16.25), wound contamination degree (OR: 7.20; 1.25-26.52) and surgical reintervention in a time inferior to one month (OR: 6.29; 2.6414.94). The confidence interval width would improve if we had a greater number of cases.

\section{Germs responsible}

In Table 8, we indicate the germs responsible for the infection. A total of $33.3 \%$ was mixed flora (aerobic and anaerobic, representative of the flora that colonizes the oral cavity). The responsible germ was not identified in 11 cases (28.2\%), in five of them because no sample was taken for the microbiology study and in the remaining six because there was no bacterial growth. There was purulent exudate in the 11 cases. The total number of germs exceeds by 3 the 
de infección fue del 1,8\% y en las no traumatológicas del 15,5\%. En la bibliografía consultada, hemos podido constatar que las tasas de infección de la herida quirúrgica en este tipo de cirugía es muy variable. En cirugía carcinogénica cérvico-facial, Penel y cols. ${ }^{6}$ señalan un porcentaje de infección del 6,6\% y Mustafa y cols. ${ }^{7}$ del $11,6 \%$. Según Penel y cols, si esta cirugía se acompaña de apertura de mucosas de vías aereo-digestivas superiores ${ }^{8}$ el porcentaje de infección puede subir al $41,8 \%$ (muy superior a la reseñada en nuestro estudio), en la que como señalamos anteriormente el porcentaje de infección en cirugía con comunicación oral fue del 12,6\%, cifra intermedia a la obtenida por De Melo en cáncer oral ${ }^{9}$ con $22,7 \%$ y Magrin y cols ${ }^{10}$ en glosectomías con $16 \%$ y a la de Simons y cols, ${ }^{11}$ en cirugía contaminada de cabeza y cuello que presenta porcentajes de infección del 8,1\%). Estos porcentajes son prácticamente similares a los de nuestro estudio, cuando analizamos sólo los procesos malignos que se realizan en la cavidad oral o tienen comunicación con ella, obtenemos una incidencia de infección del sitio quirúrgico del $26,9 \%$, mientras que en los que no existía comunicación el porcentaje fue del 8,7\%.

En lo que respecta a la cirugía traumatológica, las cifras de infección son también muy variables. Abubaker y Rollert'12 señalan cifras del $13,3 \%$ de infección en fracturas de mandibula, lizuka y cols, ${ }^{13}$ del $6,1 \%$ y Heit y cols, ${ }^{14}$ del $3,7 \%$. Todos ellos superiores a los resultados de nuestro estudio, que fueron del $1,8 \%$.

En el análisis bivariante de los factores de riesgo preoperatorio de infección quirúrgica, encontramos, con significación estadística, 5 variables: Los días de estancia preoperatoria, la duración de la intervención, la existencia de comunicación con la cavidad oral, la existencia de reintervención y el tratarse de un proceso maligno.

Naturalmente las causas que hacen que estos factores aparezcan como de riesgo pueden ser muy diversas, por ejemplo en el caso de la estancia preoperatoria, puede estar implicado el hecho de encontrarse el enfermo en un mal estado general que puede condicionar una inmunodeficiencia. En el caso de tratarse de un proceso maligno puede implicarse además de la inmunidad deficiente, un aumento en la duración de la intervención, recibir tratamiento citostático, etc.

En lo que respecta a la edad, que puede considerarse como factor de riesgo, nuestro estudio aporta el siguiente resultado: si comparamos cada grupo de edad con el resto de la muestra, observamos que el pertenecer al grupo de edad de 20 a 39 años actuaría como factor protector frente a la infección, mientras que el grupo de 60 a 79 años lo haría como factor de riesgo. Como veremos a continuación, el factor edad pierde significación en el estudio multivariante.

En el análisis bivariante, el grado de contaminación de herida no resulta estadísticamente significativo como factor de riesgo (a no ser que estratifiquemos según la malignidad-benignidad del proceso); $\sin$ embargo, la existencia de comunicación oral sí lo es, y el aumento tan importante de la incidencia de infección en la cirugía de este territorio, no puede explicarse solo por el hecho de tratarse de una cirugía limpia-contaminada debiendo incidir otros factores que no hemos considerado en nuestro estudio (existencia de traqueostomía).

El estado físico del paciente según la Clasificación de la American Society of Anesthesiologists (ASA), no resultó en nuestro estudio number of infections because three samples with growth of two germs were identified in the microbiological study.

\section{Discussion}

Infection incidence in minor surgery such as exodontias is very low, less than $1 \%, 5$ however, in major surgeries, the infection percentage increases considerably, and can reach values superior to $40 \%$.

The incidence of surgical infection in all the surgical interventions of the Maxillofacial Service of our Center was 9.4\%. In the traumatological surgical interventions, the infection percentage was $1.8 \%$ and in the non-traumatological ones $15.5 \%$. In the references consulted, we could verify that the infection rates of surgical wound in this type of surgery vary greatly. In cervico-facial carcinogenic surgery, Penel et al. ${ }^{6}$ mentioned an infection percentage of $6.6 \%$ and Mustafa et al. ${ }^{7}$ of $11.6 \%$. According to Penel et al., if this surgery is accompanied by opening of the upper aerodigestive tract mucosae(8), the percentage of infection may reach $41.8 \%$ (much greater than that shown in our study); in this setting, as we mentioned previously, the percentage of infection in surgery with oral communication was $12.6 \%$, an intermediate value to that obtained by De Melo in oral cancer ${ }^{9}$ of $22.7 \%$ and Magrin et al. ${ }^{10}$ in glossectomies with $16 \%$ and to that obtained by Simons et al. ${ }^{11}$ in head and neck contaminated surgery that showed infection percentages of $8.1 \%$. These percentages are practically the same as those of our study. When we only analyzed the malignant conditions that were performed in the oral cavity or that had communication with it, we obtained an infection incidence of the surgical site of $26.9 \%$ while the percentage was $8.7 \%$ in those in which there was no communication.

In regards to traumatologic surgery, the infection rates also vary greatly. Abubaker and Rollert ${ }^{12}$ mention values of $13.3 \%$ of infection in mandible fractures, lizuka et al. ${ }^{13} 6.1 \%$ and Heit et al. ${ }^{14} 3.7 \%$. All of these are superior to the results of our study that were $1.8 \%$.

In the bivariate analysis of the pre-operative risk factors of surgical infection, we found 5 variables with statistical significance: the days of pre-operative stay, duration of the surgical intervention, existence of communication with the oral cavity, existence of reintervention and it being a malignant condition.

Naturally, the causes that make these factors appear as a risk may be diverse. For example, in the case of pre-operative study, the fact that the patient has a general poor condition that may condition an immunodeficiency may be involved. When dealing with a malignant condition, an increase in the duration of the surgical intervention, receiving cytostatic treatment, etc. in addition to deficient immunity may also be involved.

In regards to age, which may be considered as a risk factor, our study provides the following result: if we compare each age group with the rest of the sample, we observe that 
estadísticamente significativo como factor de riesgo de infección, aunque esta tasación, toma en consideración una serie de factores del huésped que están directamente relacionados con el riesgo de infección, incluyendo: edad, estado nutricional, presencia de enfermedades sistémicas y mortalidad proyectada. ${ }^{4}$

En el análisis multivariante, encontramos como predictores independientes de infección tres variables: tiempo de intervención, grado de contaminación de la herida quirúrgica y la reintervención. Los tres parámetros están altamente comprobados en todo tipo de cirugía y los dos primeros están incluidos como tales en el estudio NNIS.

Finalmente, en este trabajo la incidencia de infección aumenta escalonadamente a medida que aumenta la puntuación del índice NISS.

En lo que respecta al análisis bacteriológico y si tenemos en cuenta que en $25(69,4 \%)$ de las 36 infecciones existía comunicación con cavidad oral, es lógico que el $33 \%$ de nuestros enfermos presentara infección por flora mixta (aerobia y anaerobia), flora que coloniza habitualmente este territorio, ${ }^{15}$ quizá este porcentaje sería mayor si hubiésemos identificado microbiológicamente a las 11 infecciones que en nuestro estudio no pudimos hacerlo. Posiblemente como comentamos antes, por estar los enfermos bajo tratamiento antibiótico, lo que pudo interferir en el resultado de los cultivos.

Es indudablemente necesario en un próximo estudio, unificar la profilaxis antibiótica, ya que en éste, ha resultado muy diversa, tanto por la variedad de los antibióticos empleados, como por la duración de la misma y por tanto no hemos podido analizar este factor ni obtener conclusiones válidas a este respecto. También es necesario introducir otros factores de riesgo, como la realización de traqueostomía acompañante a la cirugía principal y el factor cirujano, que no pudo incluirse en este estudio, a pesar de haber sido recogido el dato, por no disponer de un número suficiente de casos asignables a cada uno de ellos que permitiese un análisis estadístico significativo.

\section{Conclusiones}

Aunque nuestra tasa de infección del sitio quirúrgico considerada globalmente, no la podemos comparar con estudios similares, ya que en ella incluimos cirugía tan diversa como traumatológica facial, tumores de parótida, de lengua, de cavum, de cuello, etc., cuando la desglosamos, obtenemos unos resultados similares a los reseñados en la bibliografía en lo que se refiere a tumores maligno e inferior, si nos referimos a cirugía traumatológica.

Los factores identificados en nuestro estudio como predictores independientes de infección fueron: el tiempo de intervención, el grado de contaminación de la herida quirúrgica y la reintervención.

\section{Bibliografía}

1. Owens WD, Felts JA, Spitznagel EL. ASA physical satatus Classifications: A Study of Consistency et Rating. Anesthesiology 1978;49:239-43.

2. Horan TC, Gaynes RP, Martone W], Jarvis WR, Emori TG. CDC definitions of nosocomial surgical site infections 1992: A modifications of CDC definitions of surgical wound infections. Infect Control Hos. Epidemiol 1992; 13:606-8. belonging to the 20 to 39 year old age group would act as a protective factor against the infection while belonging to the 60 to 79 year old group would be a risk factor. As we will see in the following, the age factor loses significance in the multivariate study.

In the bivariate analysis, the wound contamination degree is not statistically significant as a risk factor (unless we stratify it according to the malignancy-benignancy of the condition), however the existence of oral communication is one. Furthermore such an important increase of the infection incidence in the surgery of this territory cannot be explained only by the fact of being clean-contaminated surgery, and other factors that we have not considered in our study (existence of tracheostomy) must play a part.

The physical condition of the patient according to the Classification of the American Society of Anesthesiologists (ASA) is not statistically significant in our study as a risk factor of infection, although this evaluation takes into consideration a series of host factors that are directly related with the risk of infection, including: age, nutritional status, presence of systemic diseases and projected mortality. ${ }^{4}$

In the multivariate analysis, we found three variables as independent predictors of infection: surgical intervention time, surgical wound contamination degree and reintervention. The three parameters are highly verified in all types of surgery and the first two are included as such in the NNIS study.

Finally, in this study, the infection incidence increases step by step as the NISS index score increases.

In regards to the bacteriological analysis and if we consider that 25 (69.4\%) of the 36 infections had communication with the oral cavity, it is logical that $33 \%$ of our patients would present infection due to mixed flora (aerobic and anaerobic), flora that usually colonizes this territory, ${ }^{15}$ and perhaps this percentage would be greater if we had microbiologically identified the 11 infections in our study which could not be identified. Possibly, as we commented on before, being patients receiving antibiotic treatment may interfere in the results of the cultures.

Undoubtedly, it is necessary to unify antibiotic prophylaxis in a future study since, in this one, it has been very diverse, both due to the variety of the antibiotics used as well as by their duration and thus we could not analyze this factor or obtain valid conclusions in this regards. It is also necessary to introduce other risk factors, such as the performance of tracheostomy accompanying the main surgical and the surgeon factor, that could not be included in this study, even though the information had been obtained, as the number of cases assignable to each one of them was not enough to allow for a statistically significant analysis.

\section{Conclusions}

Although our rate of infection of the surgical site considered globally cannot be compared with similar studies, since we include such different surgery as facial traumatol- 
3. Culver DH, Horan TC, Gaynes RP, et alt. Surgical wound infection rates by wound class, operative procedure and patient risk index. Am J Med (supp B) 1991;3B:1527.

4. Garibaldi RA, Cushing D, Lerer T. Risk Factor for Postoperative Infection. Am J Med (supp B) 1991;3B:158-62.

5. Peterson LJ. Antibiotic prophylaxis against wound infections in oral and maxillofacial surgery. J Oral Maxillofac Surg 1990;48:617-20.

6. Penel N, Fournier C, Kara A, Savini J, Lefebre D. Chimiotherapie anti-cancéreuse, facteur de risque d'infections du site opératoire en chirurgie prope cervico-faciale. Presse Med 2001;30:892-5.

7. Mustafa E, Tashin A. Cefotaxime prophylaxis in mayor non contaminated head and neck surgery: one day versus seven days therapy. J Laryngol Otol 1992;7:302.

8. Penel N, Lefebre D, Fournier C, Sarini J, Kara A, Lefebre JL. Risk factor for wound infection in head and neck cancer surgery: a prospective study. Head Neck 2001; 23:447-55.

9. De Melo GM, Ribeiro KC, Kowalski LP, Deheinzelin D. Risk factors for postoperative complications in oral cancer and their prognostic implications. Arch Otolaryngol Head Neck Surg 2001;127:828-33.

10. Magrin J, Kowalski LP, Saboia M, Saboia RP. Major glossectomy: end results of 106 cases. Eur J Cancer B Oral Oncol 1996;32B:407-12.

11. Simons JP, Johnson JT, Yu VL, Vickers RM, Gooding WE, Myers EN, Pou AM, Wagner RL, Grandis JR. The role of topical antibiotic prophylaxis in patients undergoing contaminated head and neck surgery with flap reconstruction. Laryngoscope 2001;111:329-35.

12. Abubaker AO, Rollert MK. Postoperative antibiotic prophylaxis in mandibular fractures: A preliminary randomized, double-blind, and placebo-controlled clinical study. J Oral Maxillofac Surg 2001;59:1415-9.

13. lizuka $T$, Lindqvist $C$, Hallikainen $D$, Paukku P. Infection after rigid internal fixation of mandibular fractures: a clinical and radiologic study. J Oral Maxillofac Surg 1991; 49:585-93.

14. Heit JM, Stevens MR, Jeffords K. Comparison of ceftriaxone with penicillin for antibiotic prophylaxis for compoun mandible fractures. / Oral Maxillofac Surg 1997;83:423-6.

15. Hart CA. Defence Against Colonization and Infection. En: Vincent JL(ed). Update in Intensive Care and Emergency Medicine, Volume 7. Berlin Heidelberg: Edit. Springer-Verlag 1989:14-5. ogy, parotid tumors, tongue, cavum, neck tumors, etc., when we break them down, we obtain results that are similar to those mentioned in the references that refer to malignant tumors and that are inferior if we refer to traumatology surgery.

The factors identified in our study as independent predictors of infection were: surgical intervention time, surgical wound contamination grade and reintervention. 